\title{
A peer-educator intervention: Attitudes towards LGB in prevocational secondary education in the Netherlands
}

\section{Marieke Kroneman, Wilfried Admiraal \& Mieke Ketelaars}

To cite this article: Marieke Kroneman, Wilfried Admiraal \& Mieke Ketelaars (2018): A peer-educator intervention: Attitudes towards LGB in prevocational secondary education in the Netherlands, Journal of LGBT Youth, DOI: 10.1080/19361653.2018.1531101

To link to this article: https://doi.org/10.1080/19361653.2018.1531101

Published online: 14 Nov 2018.

Submit your article to this journal $\sqsubset$

View Crossmark data 5 


\title{
A peer-educator intervention: Attitudes towards LGB in prevocational secondary education in the Netherlands
}

\author{
Marieke Kroneman $^{\mathrm{a}}$ (D), Wilfried Admiraal ${ }^{\mathrm{b}}$ (D), and Mieke Ketelaars ${ }^{\mathrm{c}}$ (D) \\ ${ }^{a}$ The Hague University of Applied Sciences, The Hague, The Netherlands; ${ }^{b}$ Leiden University \\ ICLON, Leiden, The Netherlands; 'The Hague University of Applied Sciences, The Hague, The \\ Netherlands
}

\begin{abstract}
Not many interventions are available to improve the school climate for lesbian, gay, and bisexual (LGB) youth in prevocational secondary education. In four schools with different student populations, this study examined the impact of a newly designed peer-educator intervention on attitudes towards lesbian women and gay men and on the class climate for LGB youth. The possibility of disclosing a non-heterosexual orientation in school was also assessed, using a pretest, posttest one-group design. We found limited and marginal effects of the intervention. Some evidence that the intervention was better tailored to the needs of female students is discussed.
\end{abstract}

\section{ARTICLE HISTORY}

Received 30 August 2017

Revised 27 September 2018

Accepted 28 September 2018

\section{KEYWORDS}

sexual prejudice;

intervention; peer

education; prevocational

secondary education

\section{Introduction}

In secondary school, homophobic language is common, even in the Netherlands where there is high acceptance of homosexuality in the adult population (Keuzenkamp \& Kuyper, 2013). As a consequence, students in Dutch secondary schools who identify as lesbian, gay, or bisexual (LGB) report more mental health problems compared to their heterosexual peers (Kuyper, 2015; van Bergen, Bos, Lisdonk, Keuzenkamp, \& Sandfort, 2013). Considerably more LGB students skip classes (21\%) compared to heterosexual peers (9\%). In general, LGB students judge the atmosphere in class and their relationships with teachers less positively than their heterosexual peers do (Kuyper, 2015). In addition, adolescents in the age range of 13-18 years have prevailingly negative attitudes towards their lesbian and gay peers (Heinze \& Horn, 2009; Hooghe \& Meeusen, 2012). Kuyper (2015) found that only one out of ten Dutch adolescents think LGB peers are safe to disclose their sexuality at school. Most adolescents (39\%) think it is only possible to come out to friends, while $23 \%$ think it is not possible at all to come out at school. In the context of the high acceptance of homosexuality 
in the Dutch population overall, these numbers might be considered significant.

Interestingly, when compared with girls, boys are less accepting of lesbians and gay men (Mata, Ghavami, \& Wittig, 2010), are less willing to remain friends with lesbian and gay classmates (Poteat, Espelage, \& Koenig, 2009), and are less inclined to change their negative attitudes after an intervention (Finken, 2002; Mundy-Shephard, 2015). Moreover, students in different educational tracks differ in the extent they show sexual prejudice. Students from prevocational secondary education show less positive attitudes towards homosexuality compared to their peers in academic tracks (Aerts, Dewaele, Cox, \& van Houtte, 2014; Kuyper, Roos, \& Iedema, 2014). Students in Dutch prevocational secondary education (Grades 7-10) are prepared for further vocational training and education. The difference in attitudes between vocational and academic tracks may be the result of differences in the ethnic background of both student populations, with relatively more Turkish and Moroccan students attending vocational education. Evidence supporting this notion comes from other research (Collier, Bos, Merry, \& Sandfort, 2013; Hooghe \& Meeusen, 2012) that already showed that students with a Turkish and Moroccan background show relatively less positive attitudes towards lesbians and gay men.

Schools for primary and secondary education might provide a context for remedying sexual prejudice amongst adolescents. In the Netherlands, schools for primary and secondary education are obligated by law to promote a respectful school environment for students from sexual minority groups (Dutch Ministry of Education, Arts and Sciences, 2010). However, the Dutch Inspectorate of Education recently concluded that education on sexual diversity is incidental in character, lacks clear objectives, and depends on the preferences of individual teachers because it is not embedded in the curriculum. In addition, schools have very little knowledge of the outcomes of their efforts in creating a respectful environment for sexual diversity (Dutch Inspectorate of Education, 2016). As such, there is room for improvement concerning respect for sexual diversity in schools. Unfortunately, not many interventions are available for improving secondary schools' climate in an effective way. Firstly, most intervention studies are carried out in higher education (e.g. Kwon \& Hugelshofer, 2012; Rogers, McRee, \& Arntz, 2009). Yet we know that negative attitudes are already visible in younger student populations (Collier et al., 2013; Heinze \& Horn, 2009) and that most LGB youth will come out during early adolescence (Russel, Toomey, Ryan, \& Diaz, 2014). Secondly, interventions often use strategies such as showing a film or providing instructional content, so that ignorance is taken away (Kwon \& Hugelshofer, 2012; Rogers et al., 2009). These interventions offer limited 
pedagogical variety and are focused on transmitting information and tolerant values (Tucker \& Potocky-Tripodi, 2006). Thirdly, interventions are usually executed by teachers or other adults, whereas interventions for sexual health show that peer influence and peer learning may, in fact, be a more effective strategy because, generally, teens are more receptive to their peers (Harden, Oakley, \& Oliver, 2001; Lee, Donlan, \& Paz, 2009; Sriranganathan et al., 2014). In contrast to teachers or LGB adult interventionists, peer educators have less emotional distance with students, bring an open attitude that is conducive to sharing perspectives through dialog and interaction, and create room for disagreement (Lee et al., 2009; Wernick, Dessel, Kulick, \& Graham, 2013). In the current study, we provide insights into the effects of a newly designed intervention on students' attitudes towards sexual diversity; the intervention is tailored to the needs of the student population of prevocational secondary education and uses peer education.

\section{Interventions against sexual prejudice}

In their review of 159 interventions (predominantly with adults), Bartoş, Berger, and Hegarty (2014) distinguished four types of interventions: (1) education (32 studies), (2) contact-plus-education (27 studies), (3) intergroup contact (12 studies) and (4) a social norms and expertise approach (11 studies). Interventions in the 'education' category provide information on sexual prejudice, homosexuality, or lesbian, gay, and bisexual (LGB) lives through lectures, films, scientific readings, or workshops. The studies categorized as 'contact-plus-education' use a combined approach of intergroup contact and education, usually in the form of speaker panels. The interventions within the 'contact' category consist of intergroup contact in the form of a panel presentation, film, or imagined contact with lesbian women, gay men and bisexual people. These interventions are typically based on the intergroup contact theory, which states that positive contact between members of the out-group and members of the in-group will result in less negative attitudes towards members of the out-group (Allport, 1954). Intergroup contact has repeatedly been confirmed as a way to decrease sexual prejudice in adolescents (Collier et al., 2013; Heinze \& Horn, 2009; Hooghe \& Meeusen, 2012; Mata et al., 2010; Pettigrew \& Tropp, 2006). The fourth category, the social norms and expertise approach, is a different kind of intervention. These interventions aim to reduce prejudice by setting a norm for tolerance, either by a peer group or by experts. Of the studies on social norms interventions discussed in the review by Bartoş et al. (2014), 50\% examined the effect of the source of normative influence (peers versus experts), whereas the other studies 
examined the effect of manipulating norms (legitimizing or condemning sexual prejudice) on sexually prejudiced behavior.

Overall, Bartoş et al. (2014) conclude that interventions which combine education and contact (category 2) are the most effective. An example of this kind of intervention is a one-off speaker panel (Eick, Rubinstein, Hertz, \& Slater, 2016; Kwon \& Hugelshofer, 2012), a 6-week summer camp for late adolescents which included several days of contact with homosexuals who held formal and informal presentations (Riordan, 1978), a one day discussion meeting of 14-18-year-old participants with lesbian, gay, bisexual and transgender (LGBT) volunteers (Boulden, 2004), and an intervention for 13-18-year-old students consisting of several sessions executed by teachers (Van de Ven, 1995).

Although many evaluations of interventions against sexual prejudice have found positive effects, it is unknown whether the effects will hold for younger age groups of prevocational secondary education. For example, Bucx, Van der Sman, and Jalvingh (2014) found that an intervention focused on the acceptance of homosexuality and bisexuality had no impact on students' acceptance of sexual diversity. Their participants were students under eighteen years of age and who attended secondary schools in the Netherlands. In addition, three out of five interventions for thirteen to eighteen-year-olds that are known to be effective are not suitable for integration in the school curriculum. Moreover, many interventions include professionals or teachers as the interventionists of the education, contactand-education, or contact programs, while interventions with peer educators are scarce. Peer-educators for sexual and relationship education interventions generally show a positive impact on sexual knowledge and behavior (Benni et al., 2016; Forrest, Strange, \& Oakley, 2002). Students rate these peer-led lessons positively because they feel treated equally, assess information from the peer-educator experiences as very informative and valuable, and think the lessons are fun (Benni et al., 2016; Forrest et al., 2002). One of the strengths of peer education for sexual health education is the acceptability of messages spread by peers (Sriranganathan et al., 2014). In line with the results of research by Forrest et al. (2002) peer educators are perceived by students as more credible sources of information than adult teachers. Wernick et al. (2013) found a positive impact of peer-led education and dialog on willingness to help a bullied LGBT peer. In addition, peer education is also found to benefit the peer educators, which is a relevant finding for the effectiveness of peer education interventions in the long run. For example, Borgia, Marinacci, Schifano, and Perucci (2005) found that students of the peer-led intervention improved their knowledge on HIV significantly compared to students in the teacher-led intervention. Yet peer education also knows some potential risks. Some peer education 
interventions require quite some training of peer educators, who often develop their teaching skills and beliefs while carrying out peer education. Campbell and MacPhail (2002) and Fields and Copp (2015) show how inadequate training can result in applying more traditional teaching methods. Backett-Milburn and Wilson (2000) found that peer educators were not capable to peer-teach in a classroom situation and instead choose to transfer their messages to individual classmates and friends in and outside school. Gay Straight Alliances (GSAs) which aim to make LGBT issues visible and offer support to LGBT students are also peer-led. Studies on the impact of Gay Straight Alliances show positive effects on measures of well-being of LGB students (Marx \& Kettrey, 2016; Poteat, Sinclair, DiGiovanni, Koenig, \& Russell, 2013). In accordance, Meyer and Bayer (2013) plead for participatory approaches to provide students the opportunity to formulate their own ideas about LGBT rights and lifestyles.

In order to examine the effects of an intervention on sexual prejudice in prevocational secondary schools, we developed a sequenced intervention for students of 13-18 years old, which is peer-led and has a participatory style. The following research questions guided our study:

1. What are the effects of the peer-led participatory intervention on the social acceptance of sexual diversity of thirteen to eighteen-yearold students?

2. Is this effect different for males and females?

These research questions were answered in four studies. The first study was carried out in 2014 and will be presented as a pilot study. Based on the findings from this study, we redesigned the intervention, which was examined in Studies 2, 3 and 4 (in 2015 and 2016). For purposes of clarity, the intervention will be described in Study 1, and revisions of the intervention are highlighted in Studies 2, 3 and 4 (see Table 1 for an overview). Throughout this paper we use the term LGBT to include the broad spectrum of sexual and gender diversity and for the sake of readability. However, we only measured the effects on the attitude towards sexual diversity, i.e. LGB people.

\section{Methods}

\section{A peer-educator intervention}

LGBT and heterosexual students from universities of applied sciences were recruited as peer educators. Intakes were held to explain the requirements of the project. Training of the peer educators on the program elements consisted of four afternoon/evening sessions. Supervision meetings for the peer educators were held halfway through the implementation of the intervention. 


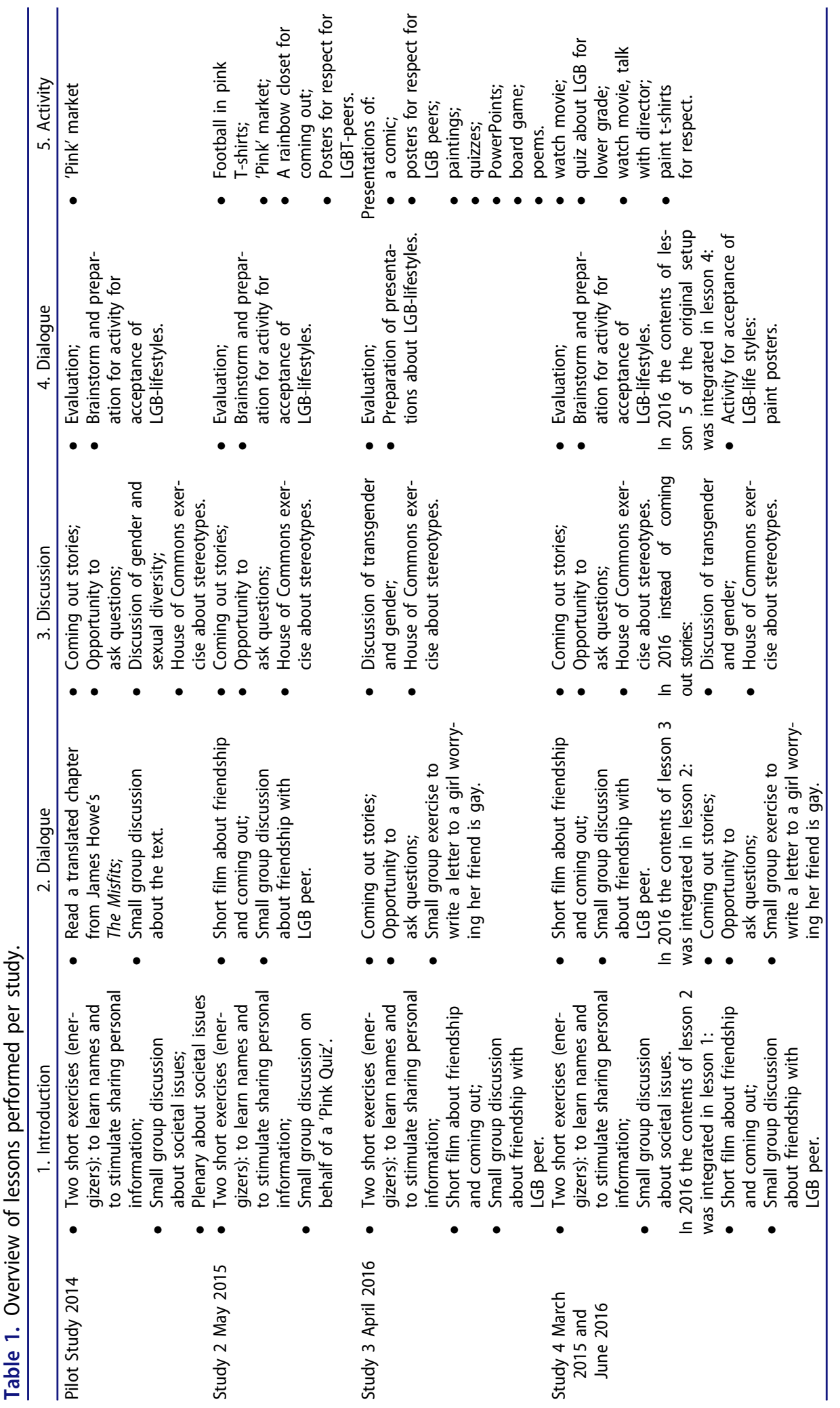


The intervention consisted of four lessons and a fifth session in which students carried out an activity to promote respect for lesbians, gay men and bisexual (LGB) people, over a period of six weeks. The goal of the intervention was to increase the acceptance of LGB peers by means of stimulating contact and the exchange of opinions between LGBT and heterosexual peer educators and students, and among students. Based on Gordon Allport's contact theory, we expected that contact between members of an in-group (heterosexuals) with members of an out-group (LGB people) would decrease prejudice (Allport, 1954). Indeed, reviews of intervention studies on reducing prejudices that applied contact theory by organizing contact between members of the biased in-group with members from the out-group confirm that intergroup contact reduces prejudice (Paluck \& Green, 2009; Pettigrew \& Tropp, 2006). Wright, McLaughlin-Volpe and Ropp (1997) developed a theory of extended contact which theorizes that watching friendly cooperation of members of the in-group with members of the out-group offers an opportunity for developing less prejudice to the members of the in-group. Peer educators did not impose views or attempt to amend opinions of students but talked about their views and personal experiences. In addition, students were informed about respectful ways to talk about LGB people through fostering a respectful vocabulary. At the same time they were invited to ask personal questions to the peer educators and to provide their own perspective on LGB issues so that they could develop their own opinions. Teachers were present in case of disruptive behavior by students, so that the peer educators could stay in their role as coach and peer.

In the first lesson, the main activity consisted of small group discussions in order to create a priority list of societal issues (Desmond, 2005). The exercise was followed by a plenary activity in which every group's top three social issues was discussed. Also, one or two energizers were carried out. The second lesson started with a short exercise, followed by the creation of a mind map. In addition, a chapter about bullying from a Dutch translation of The Misfits by James Howe was read by the students. On the basis of questions, students discussed what they would do if an LGB friend was teased. In the third lesson, the LGBT peer educators reported on their coming out, whereas the heterosexual peer educators reported on their identity development. After the personal stories students could ask questions. Also, a presentation was given about gender non-conformism and how socially conventional rules conflict with the obligation to respect everybody's choices. In addition, a House of Commons debate was carried out. In the fourth lesson, the previous lessons were evaluated in small group dialogs led by a peer educator. Also, the students were invited to bring up ideas for an activity that could promote respect for LGB peers in their school. 
Based on Study 1, several adaptions were made in studies 2, 3 and 4 . Feedback by peer educators suggested that lessons of $90 \mathrm{~min}$ were too long for the concentration span of the students. In Study 2, lessons were therefore shortened to 40 or $50 \mathrm{~min}$. Secondly, reading a chapter from Howe's The Misfits was considered dull by the peer educators. In addition, the subject of gender non-conformism and the exercises and theoretical discussions related to this subject were eliminated as peer educators found the information too difficult to explain.

As Study 3 was carried out at a school with a substantial share of students with a migrant background, small modifications were made to transfer knowledge about LGB people. The contents of lesson 2 were integrated in the introductory session. Instead of small group discussions about societal issues, a movie on friendship and coming out was shown followed by small group discussions about contact with a LGB peer. Content parts of lesson 3 were integrated in the second lesson: peer educators told their coming out story and students applied the newly acquired knowledge in writing a letter to a fictional girl who worried her friend was gay. In the third lesson a short topic about (trans)gender was added on request of the peer educators. The fourth lesson remained similar to Studies 1 and 2. On request of the school the fifth lesson consisted of short presentations about respect for LGB peers by the students.

In Study 4, the intervention was carried out in one school at two different school years. Between school years only small adaptations were made based on evaluation of the intervention. Similar to Study 3, more emphasis was laid on knowledge and introduction to LGB people as the school had a largely multicultural student population. The lessons 4 and 5 were scheduled together in the second year of implementation. For the complete lesson scheme, we refer to Table 1.

\section{Study 1: Pilot}

\section{Sample}

The participants of Study 1 were 60 Grade- 8 students (30 male) of a prevocational secondary school with mostly students of Dutch ethnicity. The mean age of the students was 13.9 years $(S D=0.7)$ (Tables 2 and 3 ).

\section{Data collection}

A pretest post-test one group design was used. Pretests were carried out one week before the first intervention lesson. Post-tests were carried out a week after the fourth lesson of the intervention. 


\section{Measures and analyses}

A shortened version of a questionnaire from the Dutch Institute of Social Cultural Planning (Bucx et al., 2014) was administered, measuring students' attitude toward gender and sexual diversity, their perception of the class climate for LGB peers, and intentions to help a bullied LGB peer. The questionnaire consisted of 16 items (see Appendix A).

\section{Attitude towards gender and sexual diversity scale}

Our scale for attitude towards gender and sexual diversity consisted of five items (Cronbach's $\alpha$ pretest $=.82$; post-test $=.77$ ). We used a 5-point Likert scale with 1 'strongly disagree' to 5 'strongly agree'. All items were recoded, which means the higher the score, the more positive attitudes are towards gender and sexual diversity.

\section{Class climate for LGB-peers scale}

A three item scale (Cronbach's $\alpha$ pretest $=.81$; post-test $=.86$ ) measured the possibility that students and teachers could be open about their sexual identity. For this scale we used a 6 -point Likert scale with $1=$ 'never' to $6=$ 'always'.

\section{Intention to help a bullied LGB-peer scale}

The scale consisted of six items that were prompted after a short vignette: 'Imagine, a boy [girl] in your class (also) fancies boys [girls] - so, he [she] is gay [lesbian] or bisexual - and classmates make jokes about that or gossip about him [her]. What would you do?' Students could choose more than one answer. All answers were ultimately scored binary, based on whether a student would take action or not $(\mathrm{KR}-20$ pretest $=.67$; post-test $=.71$ ). Vignettes were based on the gender of the participants, with female participants receiving a female vignette.

We performed separate repeated measures ANOVAs, with time and gender as independent variables and the three scale scores as dependent variables.

\section{Results pilot study 2014}

For attitudes towards sexual and gender diversity, we found a main effect of time $\left(F(1,58)=6.075, p=.017, \eta^{2}=.095\right)$, indicating that students showed less positive attitudes after the intervention. We also found a main effect of gender $\left(F(1,58)=10.72, p=.002, \eta^{2}=.156\right)$ indicating that male students were less positive than female students during the intervention. 
Table 2. Mean scores at pretest and post-test assessments in Pilot Study 1.

\begin{tabular}{|c|c|c|c|c|c|c|}
\hline & \multicolumn{2}{|c|}{ Males $n=30$} & \multicolumn{2}{|c|}{ Females $n=30$} & \multicolumn{2}{|c|}{ All $N=60$} \\
\hline & $M$ & $S D$ & M & $S D$ & M & $S D$ \\
\hline \multicolumn{7}{|c|}{ Attitude towards gender and sexual diversity ${ }^{a}$} \\
\hline Pretest & 3.03 & 0.94 & 3.78 & 0.91 & 3.40 & 0.99 \\
\hline Post-test & 2.85 & 0.70 & 3.44 & 0.96 & 3.15 & 0.89 \\
\hline \multicolumn{7}{|c|}{ Class climate for LGB-peers ${ }^{\mathrm{a}}$} \\
\hline Pretest & 2.77 & 1.31 & 2.47 & 1.68 & 2.62 & 1.50 \\
\hline Post-test & 2.37 & 1.45 & 2.88 & 1.39 & 2.63 & 1.43 \\
\hline \multicolumn{7}{|c|}{ Intention to help bullied LGB-peer ${ }^{b}$} \\
\hline Pretest & 0.43 & 0.32 & 0.46 & 0.31 & 0.45 & 0.31 \\
\hline Post-test & 0.32 & 0.32 & 0.60 & 0.36 & 0.46 & 0.36 \\
\hline
\end{tabular}

${ }^{a}$ Note. The higher the score, the more positive the attitude.

${ }^{\mathrm{b}}$ The lower the score, the less intention to help an LGB-peer.

Table 3. Time and gender main effects and interaction effects in Study 1.

\begin{tabular}{|c|c|c|c|c|c|c|c|c|c|}
\hline \multirow[b]{2}{*}{ Variable } & \multicolumn{3}{|c|}{$F$ for time $(T)$} & \multicolumn{3}{|c|}{$F$ for gender $(G)$} & \multicolumn{3}{|c|}{$F$ for $T \times G$} \\
\hline & & $p$ & $\eta^{2}$ & & $p$ & $\eta^{2}$ & & $p$ & $\eta^{2}$ \\
\hline Attitudes towards sexual and gender diversity & 6.075 & .017 & .095 & 10.715 & .002 & .156 & 0.542 & .465 & .009 \\
\hline Class climate for LGB-peers & 0.001 & .98 & $<.01$ & .121 & .73 & .002 & 3.215 & .078 & .053 \\
\hline Intention to help a bullied LGB-peer & 0.110 & .74 & .002 & 4.0 & .05 & .065 & 10.312 & .002 & .151 \\
\hline
\end{tabular}

For intention to help a bullied LGB-peer, there was a significant main effect of gender $\left(F(1,58)=4.00, p=.05, \eta^{2}=.065\right)$ and a significant interaction between time and gender $\left(F(1,58)=10.31, p=.002, \eta^{2}=.151\right)$, indicating a differential effect of gender. A paired-sample $t$ test showed a lower intention to help a bullied classmate after the intervention for males $(t(1,42)=2.02, p=.050)$ compared to the pretest scores, and an increase in intention to help a bullied classmate after the intervention for females $(t(1,33)=-2.51, p=.017)$.

\section{Studies 2, 3 and 4}

\section{Methods}

\section{Sample}

Study 2 was conducted in May 2015 in a multi-level secondary school with Grade- 8 students of all educational levels including prevocational level as well as Grade- 9 students at the prevocational level. The sample consisted of 39 students (20 males) largely from Dutch ethnic origin, of prevocational level, and with mean age of 14.4 years $(S D=0.8)$.

The participants of Study 3 were 71 Grade- 9 students $(50$ male) from a Special Educational Needs school. Educational level of almost all students (96\%) was prevocational, with a mean age of 15.3 years $(S D=0.7)$. Half of the students had a migrant background.

The participants of Study 4 were 148 Grade- 9 students (85 male) of a prevocational secondary school of whom 63 participated in March 2015 
and 85 participated in June 2016. Most students had a migrant background and their mean age was 15.3 years $(S D=0.7)$.

\section{Data collection}

A pretest post-test one group design was used. Pretests were carried out between one day and one week before the first intervention lesson. Posttests were carried out up to four weeks after the fifth lesson of the intervention. Students received a voucher to buy a drink in their school canteen after completing the pretest questionnaire.

\section{Measures and analyses}

Because of the changes in the intervention, we used slightly different measures compared to Study 1. A questionnaire with four scales was used, adapted from the regional Public Health Institute of the Netherlands (GGD Regio Nijmegen, 2008). The complete list of all scales and items per scale can be found in Appendix A.

Attitude towards Lesbians and Gay Men Scale. We used four items to measure attitude towards lesbians and gay men. Students answered items about homosexual/lesbian love, and about two girls kissing and two boys kissing in public, on a 4-point Likert type scale (the higher the score, the more positive the attitude). The reliability in terms of Cronbach's alpha ranged across the three studies from .75 to .87 at the pretest and from .72 to .85 in the post-test.

Class climate for a Gay or Bisexual Classmate Scale. We used four items for Class climate for a Gay or Bisexual Classmate (Cronbach's $\alpha$ across all three studies ranged from .74 to .76 in pretest and .67 to .85 in post-test). We used a 5 -point Likert type scale with $1=$ 'surely do not' to $5=$ 'surely do'. Three items were recoded, which means for all scales the higher the score, the more positive attitudes are.

Class climate for a Lesbian or Bisexual Classmate Scale. We used the same four items from Class Climate for a Gay or Bisexual Classmate, but then rephrased them for a lesbian or bisexual girl (Cronbach's $\alpha$ across all three studies ranged from .76 to .81 in pretest and .78 to .85 in post-test). We used a 5-point Likert type scale with $1=$ 'surely do not' to $5=$ 'surely do'. Three items were recoded, which means for all scales the higher the score, the more positive attitudes are.

Possibility of disclosing a non-heterosexual orientation in school scale. A four item scale assessed students' opinions about whether it is possible in school 
Table 4. Mean scores at pretest and post-test assessments, Study 2.

\begin{tabular}{|c|c|c|c|c|c|c|}
\hline & \multicolumn{2}{|c|}{ Males $n=20$} & \multicolumn{2}{|c|}{ Females $n=19$} & \multicolumn{2}{|c|}{ All $N=39$} \\
\hline & $M$ & $S D$ & $M$ & $S D$ & $M$ & $S D$ \\
\hline \multicolumn{7}{|c|}{ Attitude towards Lesbians and Gay Men ${ }^{\mathrm{a}}$} \\
\hline Pretest & 3.70 & 0.49 & 3.80 & 0.29 & 3.7 & 0.41 \\
\hline Post-test & 3.40 & 0.63 & 3.80 & 0.41 & 3.6 & 0.55 \\
\hline \multicolumn{7}{|c|}{ Class climate for Gay/Bi Boy ${ }^{\mathrm{a}}$} \\
\hline Pretest & 3.60 & 0.68 & 4.2 & 0.53 & 3.9 & 0.68 \\
\hline Post-test & 3.40 & 0.90 & 3.8 & 0.93 & 3.6 & 0.93 \\
\hline \multicolumn{7}{|c|}{ Class climate for Lesbian/Bi Girl ${ }^{a}$} \\
\hline Pretest & 3.80 & 0.84 & 4.0 & 0.67 & 3.9 & 0.76 \\
\hline Post-test & 3.90 & 0.97 & 3.9 & 0.73 & 3.9 & 0.85 \\
\hline \multicolumn{7}{|c|}{ Possibility of disclosing a non-heterosexual orientation ${ }^{\mathrm{b}}$} \\
\hline Pretest & 0.8 & 0.32 & 0.9 & 0.20 & 0.8 & 0.28 \\
\hline Post-test & 0.9 & 0.24 & 0.9 & 0.28 & 0.9 & 0.25 \\
\hline
\end{tabular}

${ }^{a}$ Note. The higher the score, the more positive the attitude/class climate.

${ }^{\text {b }}$ The lower the score, the less it was possible to disclose. This scale has valid responses from 17 males and 12 females.

for boys and girls to disclose that they are gay/lesbian/bisexual (KR-20 across all three studies ranged from .90 to .94 in pretest and post-test). We made items for all four non-heterosexual orientations separately. Students could answer with $1=$ 'Yes to everybody at school', $2=$ 'Yes, only to friends', $3=$ 'No', $4=$ 'I don't know'. We summed the categories 1 and 2 to $1=$ 'Yes', and recoded category 3 to $0=$ 'No'; we excluded participants who answered $4=$ 'I don't know'.

We performed separate repeated measures ANOVAs, with time and gender as independent variables and the four scale scores as dependent variables.

\section{Results study 2: Intervention May 2015}

In Table 4, we show the results of the pre- and post-tests of Study 2. For the Attitude Towards Lesbians and Gay Men Scale, we found a significant main effect of time $\left(F(1,37)=5.911, p=.02, \eta^{2}=.136\right)$. For Class Climate for a Gay or Bisexual Male Classmate Scale we also found a significant main effect of time $\left(F(1,37)=7.166, p=.011, \eta^{2}=.16\right)$ as well as a main effect of gender $\left(F(1,37)=5.45, p=.025, \eta^{2}=.13\right)$. Students were less positive towards lesbians and gay men, and towards gay and bisexual classmates after the intervention. In Table 5 we show time and gender main effects and interaction effects in Study 2.

\section{Results study 3: Intervention April 2016}

Tables 6 and 7 shows the results of Study 3. For Class Climate for a Gay or Bisexual Classmate Scale we found a main effect for gender $\left(F(1,69)=20.65, p \leq .001, \eta^{2}=.23\right)$, indicating a more positive attitude in female students during the intervention. For Possibility of Disclosing a Non-Heterosexual Orientation in School Scale, we found a significant 
Table 5. Time and gender main effects and interaction effects in Study 2.

\begin{tabular}{|c|c|c|c|c|c|c|c|c|c|}
\hline \multirow[b]{2}{*}{$\underline{\text { Variable }}$} & \multicolumn{3}{|c|}{$F$ for time $(T)$} & \multicolumn{3}{|c|}{$F$ for gender $(G)$} & \multicolumn{3}{|c|}{$F$ for $T \times G$} \\
\hline & & $p$ & $\eta^{2}$ & & $p$ & $\eta^{2}$ & & $p$ & $\eta^{2}$ \\
\hline Attitude towards Lesbians and Gay Men & 5.91 & .021 & .14 & 3.41 & .073 & .08 & 1.38 & .247 & .04 \\
\hline Class climate for Gay/Bi Boy & 7.17 & .011 & .16 & 5.45 & .025 & .13 & 0.65 & .426 & .02 \\
\hline Class climate for Lesbian/Bi Girl & .08 & .780 & $<.01$ & .13 & .717 & $<.01$ & 1.58 & .217 & .04 \\
\hline Possibility to disclose a non-heterosexual orientation ${ }^{a}$ & .75 & .396 & .03 & .20 & .656 & $<.01$ & .75 & .396 & .03 \\
\hline
\end{tabular}

${ }^{a}$ Note. This scale has valid responses of 29 participants.

Table 6. Mean scores at pretest and post-test assessments, Study 3.

\begin{tabular}{|c|c|c|c|c|c|c|}
\hline & \multicolumn{2}{|c|}{ Males $n=50$} & \multicolumn{2}{|c|}{ Females $n=21$} & \multicolumn{2}{|c|}{ All $N=71$} \\
\hline & $M$ & $S D$ & $M$ & $S D$ & M & $S D$ \\
\hline \multicolumn{7}{|c|}{ Attitude towards Lesbians and Gay Men ${ }^{a}$} \\
\hline Pretest & 3.1 & 0.85 & 3.1 & 1.00 & 3.1 & 0.89 \\
\hline Post-test & 3.0 & 0.77 & 3.3 & 0.75 & 3.1 & 0.77 \\
\hline \multicolumn{7}{|c|}{ Class climate for Gay/Bi Boy ${ }^{a}$} \\
\hline Pretest & 2.9 & 1.02 & 3.8 & 0.62 & 3.2 & 1.00 \\
\hline Post-test & 3.1 & 0.84 & 4.0 & 0.65 & 3.3 & 0.90 \\
\hline \multicolumn{7}{|c|}{ Class climate for Lesbian/Bi Girl ${ }^{a}$} \\
\hline Pretest & 3.7 & 0.85 & 3.8 & 0.73 & 3.8 & 0.81 \\
\hline Post-test & 3.7 & 0.72 & 3.9 & 0.70 & 3.8 & 0.72 \\
\hline \multicolumn{7}{|c|}{ Possibility of disclosing a non-heterosexual orientation ${ }^{b}$} \\
\hline Pretest & 0.47 & 0.40 & 0.43 & 0.41 & 0.46 & 0.40 \\
\hline Post-test & 0.55 & 0.40 & 0.52 & 0.43 & 0.54 & 0.41 \\
\hline
\end{tabular}

${ }^{a}$ Note. The higher the score, the more positive the attitude/class climate.

${ }^{\mathrm{b}}$ The lower the score, the less it was possible to disclose. This scale has valid responses from 42 males and 16 females.

Table 7. Time and gender main effects and interaction effects in Study 3.

\begin{tabular}{|c|c|c|c|c|c|c|c|c|c|}
\hline \multirow[b]{2}{*}{ Variable } & \multicolumn{3}{|c|}{$F$ for time $(T)$} & \multicolumn{3}{|c|}{$F$ for gender $(G)$} & \multicolumn{3}{|c|}{$F$ for $T \times G$} \\
\hline & & $P$ & $\eta^{2}$ & & $P$ & $\eta^{2}$ & & $p$ & $\eta^{2}$ \\
\hline Attitude towards Lesbians and Gay Men & .72 & .399 & .01 & .96 & .332 & .01 & 1.4 & .237 & .02 \\
\hline Class climate for Gay/Bi Boy & 2.62 & .110 & .04 & 20.65 & $<.00$ & .23 & .08 & .776 & $<.01$ \\
\hline Class climate for Lesbian/Bi Girl & $<.01$ & .977 & $<.01$ & .26 & .612 & $<.01$ & .11 & .740 & $<.01$ \\
\hline Possibility to disclose a non-heterosexual orientation ${ }^{a}$ & 4.03 & .050 & .07 & .11 & .740 & $<.01$ & $<.01$ & .983 & $<.01$ \\
\hline
\end{tabular}

${ }^{a}$ Note. This scale has valid responses of 58 participants.

main effect of time $\left(F(1,56)=4.03, p=.050, \eta^{2}=.067\right)$. After the intervention, the students' attitudes were more positive about the possibility of coming out at school.

\section{Results study 4: Intervention March 2015 and June 2016}

Tables 8 and 9 summarizes the results of Study 4 . For the Attitude Towards Lesbians and Gay Men Scale, we found a main effect of gender $\left(F(1,145)=18.48, p \leq 01, \eta^{2}=.113\right)$. We also found a significant interaction between time and gender $\left(F(1,145)=5.69, p=.018, \eta^{2}=.04\right)$. A pairedsamples $t$ test shows a more positive attitude towards lesbians and gay men in females after the intervention $(F(1,145)=5.63, p=.019)$, and no change for male students $(F(1,145)=.80, p=.372)$. 
Table 8. Mean scores at pretest and post-test assessments, Study 4.

\begin{tabular}{|c|c|c|c|c|c|c|}
\hline & \multicolumn{2}{|c|}{ Males $n=85$} & \multicolumn{2}{|c|}{ Females $n=63$} & \multicolumn{2}{|c|}{ All $N=148$} \\
\hline & $M$ & $S D$ & $M$ & $S D$ & M & $S D$ \\
\hline \multicolumn{7}{|c|}{ Attitude towards Lesbians and Gay Men ${ }^{a}$} \\
\hline Pretest & 2.3 & 0.91 & 2.8 & 1.02 & 2.5 & 0.98 \\
\hline Post-test & 2.3 & 0.84 & 3.0 & 0.89 & 2.6 & 0.94 \\
\hline \multicolumn{7}{|c|}{ Class climate for Gay/Bi Boy ${ }^{a}$} \\
\hline Pretest & 2.5 & 0.76 & 3.8 & 0.90 & 3.0 & 1.03 \\
\hline Post-test & 2.4 & 0.74 & 3.8 & 0.80 & 3.0 & 1.02 \\
\hline \multicolumn{7}{|c|}{ Class climate for Lesbian/Bi Girl ${ }^{a}$} \\
\hline Pretest & 3.2 & 0.92 & 3.6 & 0.88 & 3.4 & 0.92 \\
\hline Post-test & 3.1 & 0.93 & 3.7 & 0.78 & 3.4 & 0.90 \\
\hline \multicolumn{7}{|c|}{ Possibility of disclosing a non-heterosexual ${ }^{b}$ orientation } \\
\hline Pretest & 0.36 & 0.43 & 0.50 & 0.46 & 0.42 & 0.44 \\
\hline Post-test & 0.36 & 0.38 & 0.43 & 0.46 & 0.39 & 0.42 \\
\hline
\end{tabular}

${ }^{a}$ Note. The higher the score, the more positive the attitude/class climate.

${ }^{\mathrm{b}}$ The lower the score, the less it was possible to disclose. This scale has valid responses from 48 males and 35 females.

Table 9. Time and gender main effects and interaction effects in Study 4.

\begin{tabular}{|c|c|c|c|c|c|c|c|c|c|}
\hline \multirow[b]{2}{*}{ Variable } & \multicolumn{3}{|c|}{$F$ for time $(T)$} & \multicolumn{3}{|c|}{$F$ for gender $(G)$} & \multicolumn{3}{|c|}{$F$ for $T \times G$} \\
\hline & & $p$ & $\eta^{2}$ & & $p$ & $\eta^{2}$ & & $p$ & $\eta^{2}$ \\
\hline Attitude towards Lesbians and Gay Men & 1.49 & .223 & .01 & 18.48 & $\leq .01$ & .11 & 5.69 & .018 & .04 \\
\hline Class climate for Gay/Bi Boy & .10 & .749 & $<.01$ & 113.35 & $\leq .01$ & .44 & .50 & .483 & $<.01$ \\
\hline Class climate for Lesbian/Bi Girl & $<.01$ & .997 & $<.01$ & 13.57 & $\leq .01$ & .08 & .31 & .580 & $<.01$ \\
\hline $\begin{array}{l}\text { Possibility to disclose a non-heterosexual } \\
\text { orientation }^{\mathrm{a}}\end{array}$ & .71 & .402 & $<.01$ & 1.44 & .234 & .02 & .57 & .452 & $<.01$ \\
\hline
\end{tabular}

${ }^{\mathrm{a}}$ Note. This scale has valid responses of 83 participants.

For the Class Climate for a Gay or Bisexual Classmate Scale, we found a significant effect of gender $\left(F(1,146)=113.35, p \leq 001, \eta^{2}=.44\right)$. Also, for the Class Climate for a Lesbian or Bisexual Classmate Scale there was a main effect of gender $\left(F(1,146)=13.6, p \leq 01, \eta^{2}=.08\right)$. As such, female students showed more positive attitudes towards gay and bisexual male students and lesbian and bisexual female students when compared with male students.

\section{General discussion and implications}

We designed and evaluated a participatory peer-educator intervention aimed at increasing the acceptance of sexual diversity, using a pretest posttest design. Four studies were conducted with slightly adapted interventions and different student populations. Effects were measured on attitude towards gender diversity and sexual diversity, class climate, intentions to help a bullied LGB peer, and school climate for students to come out as lesbian, gay, or bisexual. Overall, we found limited effects across all four studies. For the intervention/time main effect, only four out of 15 coefficients were statistically significant. Three of the four effects were negative, suggesting the students attitudes became more negative after the 
intervention. For the gender main effect, six out of 15 coefficients were positive and statistically significant. Girls hold more positive attitudes than boys. The interaction effect for time and gender was significant in only two out of 15 coefficients, suggesting that girls are more affected by the intervention.

Negative main effects were found in schools with a slightly younger student population that generally showed a positive attitude from the start (Studies 1 and 2). In the school with students with a moderately positive attitude in general (Study 3) only one positive main effect has been found and in the school with students with a negative attitude in general (Study 4) no main effect has been found.

A possible explanation for the negative effects in Study 1 and 2 can be found in a theory of moral development such as Social Cognitive Domain Theory. According to Nucci (2009) who elaborated this theory for children and adolescents in all different age groups, youth have to learn to coordinate three domains of moral choices: the domain of social and cultural norms (conventions), the domain of moral rules about human rights, and the domain of personal autonomy. Youth in the stage of early adolescence (12-14 years) are mainly concerned with the domain of personal autonomy (Nucci, 2009). They are in a phase of negating societal and cultural norms. At this age norms are seen as arbitrary rules imposed by authorities (Nucci, 2009). The participants in the pilot study and in Study 2 were early adolescents and may have been in this phase of negation, resulting in a decrease in acceptance. Another characteristic of early adolescence, according to the social cognitive theory of Bandura (1977) is that they tend to overestimate themselves. In the pilot study and in Study 2 this overestimation may have resulted in more positive scores. Also, when students who judge themselves as very accepting of gender and sexual diversity are involved in an intervention actively seeking attitude change for more acceptance of LGBT people, this may irritate them and cause a counterproductive effect. We think especially in Study 2 this is what might have happened. Another reason that initial positive attitudes decreased after the intervention in the pilot study may be that in the lessons of $90 \mathrm{~min}$ the students were too much distracted because of their limited concentration span. In the lessons of $90 \mathrm{~min}$ with lots of group discussions and opportunities for talking students may have lost attention for the message of an LGBT affirmative attitude. In their impact study for adolescents of 11-16 year with negative effect, Mosnaim et al. (2013) think that a lack of focus on what should be achieved (the objectives) in the intervention impacts the results.

An explanation for the limited effects in Study 3 and 4 in the schools with students with a migrant background may be that a negative attitude 
towards lesbians and gays is already formed and relative stable at a very young age and relative stable at this time. Support for this hypothesis comes from Bos, Picavet, and Sandfort (2012) who found that pupils from non-Western ethnic background have a negative attitude towards gays and lesbians in elementary school in Grades 5 and 6, whereas pupils from Western ethnic background had a positive attitude. A negative attitude that exists from such a young age may very well be difficult to change (Raabe \& Beelmann, 2011).

As expected, we found some evidence for a differential effect of gender on outcome. Girls reported higher intentions to help a bullied classmate and showed more positive attitude towards lesbians and gay men after the intervention. In Study 1, females were more inclined to help a bullied LGB-peer compared to boys. This result is in accordance with Wernick et al. (2013), who found that males were less likely to intervene compared to females after a peer-led intervention in a high school. An explanation for the gender difference may be found in the nature of the intervention. Exchange of opinions and discussions with heterosexual and LGBT-peers are central to the current intervention, which may not fit the needs of males. According to Friedrich, Méndez, and Mihalas (2010), boys talk less easily about personal subjects compared to girls. Moreover, Newby, Wallace, Dunn, and Brown (2012) found that boys show a lower preference for obtaining information about sexuality from friends than girls, and that methods of sex education involving group discussion and cooperation are less favorable for boys than for girls

\section{Limitations}

Several limitations apply to the present study. Firstly, the sample sizes in each of the studies reduced statistical power. As schools had different student populations and interventions were slightly adapted over time, we opted to discuss each school separately instead of combining the results. An exception was Study 4, which consisted of the results of two separate cohorts.

In addition, the instruments may not have been tailored to the skills and needs of the participants consisting of prevocational students and students with Dutch as a second language who may have limited reading skills and low concentration. According to Sriranganathan et al. (2014), asking questions about sexual and health issues is inappropriate in some cultures and can be met with resistance.

Finally, the choice of a field intervention with peer educators, which goes beyond a cognitive approach of sharing information and teaching knowledge, implies that many factors can influence the execution of the intervention, i.e. the dynamics between students and peer educators 
(Paluck \& Green, 2009). Our intervention was implemented in a school setting, which is one of the most important contexts for students up to eighteen years of age (Newby et al., 2012). Moreover, sexual prejudice is common practice in schools of all types (Hooghe \& Meeusen, 2012). More specific information on how this kind of intervention is implemented and on interaction processes in the classroom could help to understand the impact of the intervention.

\section{Future research}

Because of the ambiguous findings future research seems to be useful. In order to increase our understanding of the effects of these interventions, it would be valuable to investigate the qualitative experiences of the students and peer educators. This will provide more understanding of potential beneficial and obstructive factors of the intervention. Similarly, qualitative research into the personal opinions and experiences of the peer educators involved in the intervention may offer us a better understanding of the intervention process itself.

Furthermore, to prevent negative outcomes due to the developmental phase of the students, we would argue for execution of the intervention with younger age groups, for example Grades 5 and 6 in primary school. Children in these grades are not yet in a phase of negating societal norms while in the process of acquiring autonomy (Nucci, 2009). At the age of eight, children are most receptive to learning social acceptance of non-conforming behavior and internalizing non-prejudiced attitudes (Raabe \& Beelmann, 2011). As such, they may be more susceptible to interventions aimed at increasing the acceptance of sexual diversity.

\section{Notes on Contributors}

Marieke Kroneman obtained her Master's degree in Philosophy of Education at Utrecht University in 1996. From 1998 until 2005, she worked as editor for the Dutch professional journal on youth welfare, youth care, and youth policy 0-25. In 2006 she started as a lecturer in tertiary education for pedagogical professions. Her research as a $\mathrm{PhD}$ student focuses on peer education and the link between sexual prejudice and citizenship education.

Wilfried Admiraal (Universiteit Leiden) is fulltime professor Educational Sciences and director of ICLON Leiden University Graduate School of Teaching. His research interest is in the combination of Education, Technology and Social Psychology in secondary and higher education. More information: https://sites.google.com/site/wilfriedadmiraal/. 
Mieke Ketelaars obtained her Master's degree in Clinical Child and Adolescent Studies at Leiden University in 2003. She then obtained her PhD from Radboud University in 2010 on the subject of classification of pragmatic language problems. During her $\mathrm{PhD}$, she also worked as a lecturer and psychologist at autism teams at Kentalis Eindhoven and Zorgverlening PGZ. Between 2013 and 2016 Mieke worked as an Assistant Professor at Leiden University, where her main focus of research was atypical manifestations of Autism Spectrum Disorders (ASD). After that, she switched to The Hague University of Applied Sciences. In addition she is Editor in chief of the Dutch journal 'Tijdschrift voor Orthopedagogiek'.

\section{ORCID}

Marieke Kroneman (D) http://orcid.org/0000-0001-8516-7691

Wilfried Admiraal (D) http://orcid.org/0000-0002-1627-3420

Mieke Ketelaars (D) http://orcid.org/0000-0002-7759-4092

\section{References}

Aerts, S., Dewaele, A., Cox, N., \& van Houtte, M. (2014). Homonegativity in the technical and vocational track: A survey of secondary school students in Flanders. Journal of LGBT Youth, 11(4), 364-387. https://doi.org/10.1080/19361653.2014.910485

Allport, G. W. (1954). The nature of prejudice. Boston, MA: Addison-Wesley Publishing Company.

Backett-Milburn, K., \& Wilson, S. (2000). Understanding peer education: Insights from a process evaluation. Health Education Research, 15(1), 85-96.

Bandura, A. (1977). Self-efficacy: Toward a unifying theory of behavioral change. Psychological Review, 84(2), 191-215.

Bartoş, S. E., Berger, I., \& Hegarty, P. (2014). Interventions to reduce sexual prejudice: A study-space analysis and meta-analytic review. The Journal of Sex Research, 51(4), 363-382. https://doi.org/10.1080/00224499.2013.871625

Benni, E., Sacco, S., Bianchi, L., Carrara, R., Zanini, C., Comelli, M., ... SISM Educators Group. (2016). Evaluation outcomes of a sex education strategy in high schools of Pavia (Italy). Global Health Promotion, 23(2), 15-29. https://doi.org/10.1177/1757975914558309

Borgia, P., Marinacci, C., Schifano, P., \& Perucci, C. A. (2005). Is peer education the best approach for HIV prevention in schools? Findings from a randomized controlled trial. Journal of Adolescent Health, 36(6), 508-516. http://dx.doi.org/10.1016/j.jadohealth.2004. 03.005

Bos, H. M. W., Picavet, C. \& Sandfort, T. G. M. (2012). Ethnicity, gender socialization, and children's attitudes towards gay men and lesbian women. Journal of Cross Cultural Psychology, 43(7), 1082-1094. doi:10.1177/0022022111420146

Boulden, W. T. (2004). Evaluation of the Anytown Leadership Institute programming on lesbian, gay, bisexual and transgender issues. Journal of Gay \& Lesbian Social Services: Issues in Practice, Policy \& Research, 17(4), 17-38. https://doi.org/10.1300/J041v17n04_02

Bucx, F., Van der Sman, F., \& Jalvingh, C. (2014). Anders in de klas [Being different in class]. Den Haag: SCP. Retrieved from https://www.scp.nl/dsresource?objectid= ab46eb70-7379-46cc-bad5-3f0f2fb864dd 
Campbell, C., \& MacPhail, C. (2002). Peer education, gender and the development of critical consciousness: Participatory HIV prevention by South African youth. Social Science \& Medicine, 55, 331-345.

CBS (2016). Jaarrapport Integratie 2016 [Annual Report Integration 2016] Den Haag: CBS. Retrieved from https://www.cbs.nl/nl-nl/publicatie/2016/47/jaarrapport-integratie-2016

Collier, K. L., Bos, H. M. W., Merry, M. S., \& Sandfort, T. G. M. (2013). Gender, ethnicity, religiosity, and same-sex sexual attraction and the acceptance of same-sex sexuality and gender non-conformity. Sex Roles, 68(11-12), 724-737. https://doi.org/10.1007/s11199012-0135-5

Desmond, S. A. (2005). Prioritizing social problems: An exercise for exploring students' attitudes about social problems. Teaching Sociology, 33(1), 59-65. https://doi.org/10. 1177/0092055X0503300105

Dutch Inspectorate of Education (2016). Themaonderzoek Omgaan met seksualiteit en seksuele diversiteit, een beschrijving van het onderwijsaanbod van scholen. [Theme Research Dealing with sexuality and sexual diversity, a description of the educational provision of schools] Den Haag: Dutch Ministry of Education, Arts and Sciences. Retrieved from https://www.onderwijsinspectie.nl/documenten/publicaties/2016/06/01/rapport-omgaan-metseksualiteit-en-seksuele-diversiteit

Dutch Ministry of Education, Arts and Sciences (2010). Kerndoelen onderbouw voortgezet onderwijs. [Core objectives Middle school secondary education] Den Haag: Dutch Ministry of Education, Arts and Sciences. Retrieved from https://www.rijksoverheid.nl/ documenten/besluiten/2010/09/17/kerndoelen-onderbouw-voortgezet-onderwijs

Eick, U., Rubinstein, T., Hertz, S., \& Slater, A. (2016). Changing attitudes of high school students in Israel toward homosexuality. Journal of LGBT Youth, 13(1-2), 192-206. https://doi.org/10.1080/19361653.2015.1087930

Fields, J., \& Copp, M. (2015). Striving for empathy: Affinities, alliances and peer sexuality educators. Sex Education, 15(2), 188-203. http://dx.doi.org/10.1080/14681811.2014.992065

Finken, L. L. (2002). The impact of a human sexuality course on anti-gay prejudice: The challenge of reaching male students. Journal of Psychology \& Human Sexuality, 14(1), 37-46. http://doi.org/10.1300/J056v14n01_03

Forrest, S., Strange, V., \& Oakley, A. (2002). A comparison of students' evaluations of a peer-delivered sex education programme and teacher-led provision. Sex Education, 2(3), 195-214. https://doi.org/10.1080/1468181022000025776

Friedrich, A. A., Méndez, L. M. R., \& Mihalas, S. T. (2010). Gender as a factor in school-based mental health service delivery. School Psychology Review, 39(1), 122-136. www.researchgate.net

GGD Regio Nijmegen (2008). E-MOVO 2007/2008. Gezondheid, welzijn en leefwijze van jongeren in de gemeente Nijmegen [E-MOVO 2007/2008. Health, wellbeing and lifestyle of youth in the municipality of Nijmegen] Nijmegen: GGD Region Nijmegen. Retrieved from https://www.nijmegen.nl/rapportenzoeker/Docs/E-MOVO\%202007_2008_sep2008.pdf

Harden, A., Oakley, A., \& Oliver, S. (2001). Peer-delivered health promotion for young people: A systematic review of different study designs. Health Education Journal, 60(4), 339-353. https://doi.org/10.1177/001789690106000406

Heinze, J. E., \& Horn, S. S. (2009). Intergroup contact and beliefs about homosexuality in adolescence. Journal of Youth \& Adolescence, 38, 93-951. https://doi.org/10.1007/s10964009-9408-x

Hooghe, M., \& Meeusen, C. (2012). Homophobia and the transition to adulthood: A three year panel study among Belgian late adolescents and young adults, 2008-2011. Journal of Youth \& Adolescence, 41(9), 1197-1207. https://doi.org/10.1007/s10964-012-9786-3 
Horn, S. S. (2007). Adolescents' acceptance of same-sex peers based on sexual orientation and gender expression. Journal of Youth \& Adolescence, 36(3), 363-371. https://doi.org/ 10.1007/s10964-006-9111-0

Huijnk, W. (2014). Acceptatie van homoseksualiteit door etnische en religieuze groepen in Nederland. [Acceptance of homosexuality by ethnic and religious groups in the Netherlands] Den Haag: SCP. Retrieved from https://www.scp.nl/dsresource?objectid $=$ f64c54f1-ae6a-4640-b3fe-3ebbf8ee715f

Jennings, J. M., Howard, S., \& Perotte, C. L. (2014). Effects of a school-based sexuality education program on peer educators: The Teen PEP model. Health Education Research, 29(2), 319-329. https://doi.org/10.1093/her/cyt153

Keuzenkamp, S., \& Kuyper, L. (2013). Acceptatie van homoseksuelen, biseksuelen en transgenders in Nederland 2013. [Acceptance of homosexual, bisexual and transgender people in the Netherlands 2013] Den Haag: SCP. Retrieved from https://www.scp.nl/Publicaties/ Alle_publicaties/Publicaties_2013/Acceptatie_van_homoseksuelen_biseksuelen_en_transgenders_in_Nederland_2013

Kuyper, L. (2015). Jongeren en seksuele orientatie. [Youth and sexual orientation] Den Haag: SCP. Retrieved from https://www.scp.nl/dsresource?objectid=c899a4ac-9081-46b9$82 \mathrm{ac}-75 \mathrm{fafc} 213047$

Kuyper, L., De Roos, S., \& Iedema, J. (2014). 'Ik vind het vies als twee jongens met elkaar zoenen.' Houding ten opzichte van lesbische, homoseksuele en biseksuele jongeren onder Nederlandse scholieren. [I think its dirty if two boys are kissing. The attitude towards lesbians gay and bisexual youth among Dutch students] Nederlands Tijdschrift voor Seksuologie, 38(2), 58-67.

Kwon, P., \& Hugelshofer, D. S. (2012). Lesbian, gay, and bisexual speaker panels lead to attitude change among heterosexual college students. Journal of Gay \& Lesbian Social Services, 24(1), 62-79. https://doi.org/10.1080/10538720.2012.643285

Lee, J., Donlan, W., \& Paz, J. (2009). Culturally competent HIV/AIDS prevention: Understanding program effects on adolescent beliefs, attitudes, and behaviors. Journal of HIV/AIDS \& Social Services, 8(1), 57-79. https://doi.org/10.1080/15381500902736194

Marx, R. A., \& Kettrey, H. H. (2016). Gay-Straight alliances are associated with lower levels of school-based victimization of LGBTQ + Youth: A systematic review and meta-analysis. Journal of Youth \& Adolescence, 45(7), 1269-1282. https://doi.org/10.1007/s10964-0160501-7

Mata, J., Ghavami, N., \& Wittig, M. A. (2010). Understanding gender differences in early adolescents' sexual prejudice. Journal of Early Adolescence, 30(1), 50-75. https://doi.org/ $10.1177 / 0272431609350925$

Meyer, I. H., \& Bayer, R. (2013). School-based gay-affirmative interventions: First amendment and ethical concerns. American Journal of Public Health, 103(10), 1764-1771. DOI: 10.2105/AJPH.2013.301385

Mosnaim, G., Li, H., Martin, M., Richardson, D., Belice, P. J., Avery, E., ... Powell, L. (2013). The impact of peer support and mp3 messaging on adherence to inhaled corticosteroids in minority adolescents with asthma: A randomized, controlled trial. Journal of Allergy \& Clinical Immunology: In Practice, 1(5), 485-493. https://doi.org/10.1016/j.jaip.2013.06.010

Mundy-Shephard, A. M. (2015). Empathy, perspective-taking and the mere exposure effect: Understanding adolescent attitudes about sexual minorities and reducing prejudice against sexual minority youth (Doctoral dissertation). Retrieved from http://nrs.harvard. edu/urn-3:HUL.InstRepos:23519640

Nucci, L. (2009). Nice is not enough: Facilitating moral development. Upper Saddle River, NJ: Pearson Education. 
Newby, K., Wallace, L. M., Dunn, O., \& Brown, K. E. (2012). A survey of English teenagers' sexual experience and preferences for school-based sex education. Sex Education, 12(2), 231-251. https://doi.org/10.1080/14681811.2011.615582

Paluck, E. L., \& Green, D. P. (2009). Prejudice reduction: What works? A review and assessment of research and practice. Annual Review of Psychology, 60(1), 339-367. https://doi.org/10.1146/annurev.psych.60.110707.163607

Pettigrew, T. F., \& Tropp, L. R. (2006). A meta-analytic test of intergroup contact theory. Journal of Personality \& Social Psychology, 90(5), 751-783. http://dx.doi.org/10.1037/ 0022-3514.90.5.751

Poteat, V. P., Espelage, D. L., \& Koenig, B. W. (2009). Willingness to remain friends and attend school with lesbian and gay peers: Relational expressions of prejudice among heterosexual youth. Journal of Youth \& Adolescence, 38(7), 952-962. https://doi.org/10. 1007/s10964-009-9416-x

Poteat, V. P., Sinclair, K. O., DiGiovanni, C. D., Koenig, B. W., \& Russell, S. T. (2013). Gay-Straight alliances are associated with student health: A multischool comparison of LGBTQ and heterosexual youth. Journal of Research on Adolescence, 23(2), 319-330. https://doi.org/10.1111/j.1532-7795.2012.00832.x

Raabe, T., \& Beelmann, A. (2011). Development of ethnic, racial, and national prejudice in childhood and adolescence: a multinational meta-analysis of age differences. Child Development, 82(6), 1715-1737. https://doi.org/10.1111/j.1467-8624.2011.01668.x

Riordan, C. (1978). Developing tolerance: A comparison of contextual versus program effects. International Journal of Intercultural Relations, 2(3), 309-327. https://doi.org/10. 1016/0147-1767(78)90016-0

Rogers, A., McRee, N., \& Arntz, D. L. (2009). Using a college human sexuality course to combat homophobia. Sex Education, 9(3), 211-225. https://doi.org/10.1080/14681810903059052

Russel, S. T., Toomey, R. B., Ryan, C., \& Diaz, R. M. (2014). Being out at school: The implications for school victimization and young adult adjustment. American Journal of Orthopsychiatry, 84(6), 635-643. http://dx.doi.org/10.1037/ort0000037

Sriranganathan, G., Jaworsky, D., Larkin, J., Flicker, S., Campbell, L., Flynn, S., ... Erlich, L. (2014). Peer sexual health education: Interventions for effective programme evaluation. Health Education Journal, 71(1), 62-71.

Tucker, E. W., \& Potocky-Tripodi, M. (2006). Changing Heterosexuals' attitudes toward homosexuals: A systematic review of the empirical literature. Research on Social Work Practice, 16(2), 176-190.

van Bergen, D. D., Bos, H. W. M., Lisdonk, J. T. A., Keuzenkamp, S., \& Sandfort, T. (2013). Victimization and suicidality among Dutch lesbian, gay and bisexual youth. American Journal of Public Health, 103(1), 70-72. DOI:10.2105/AJPH.2012.300797

Van de Ven, P. (1995). Effects on high school students of a teaching module for reducing homophobia. Basic \& Applied Social Psychology, 17(1-2), 153-172. https://doi.org/10. 1080/01973533.1995.9646137

Warwick, I., \& Aggleton, P. (2014). Bullying, 'cussing' and 'mucking about': Complexities in tackling homophobia in three secondary schools in south London, UK. Sex Education, 14(2), 159-173. https://doi.org/10.1080/14681811.2013.854204

Wernick, L. J., Dessel, A. B., Kulick, A., \& Graham, L. F. (2013). LGBTQQ youth creating change: Developing allies against bullying through performance and dialogue. Children \& Youth Services Review, 35(9), 1576-1586. https://doi.org/10.1016/j.childyouth.2013.06.005

Wright, S. C., Aron, A., McLaughlin-Volpe, T., \& Ropp, S. A. (1997). The extended contact effect: Knowledge of cross-group friendships and prejudice. Journal of Personality \& Social Psychology, 73(1), 73-90. doi:10.1037/0022-3514.73.1.73 